\title{
Nautilia nitratireducens sp. nov., a thermophilic, anaerobic, chemosynthetic, nitrate-ammonifying bacterium isolated from a deep-sea hydrothermal vent
}

\author{
Ileana Pérez-Rodríguez, ${ }^{1,2}$ Jessica Ricci, ${ }^{1,2}$ James W. Voordeckers, ${ }^{1,2} \dagger$ \\ Valentin Starovoytov ${ }^{3}$ and Costantino Vetriani ${ }^{1,2}$ \\ ${ }^{1}$ Department of Biochemistry and Microbiology, Rutgers University, New Brunswick, NJ 08901 , \\ USA \\ ${ }^{2}$ Institute of Marine and Coastal Sciences, Rutgers University, New Brunswick, NJ 08901, USA \\ ${ }^{3}$ Department of Cell Biology and Neuroscience, Rutgers University, Piscataway, NJ 08854, USA
}

Correspondence

Costantino Vetriani vetriani@marine.rutgers.edu
In deep-sea hydrothermal vents, primary productivity relies on micro-organisms that use different metabolic strategies to convert chemical energy into biochemical energy and fix carbon dioxide. It has been found that epsilonproteobacteria are abundant in deep-sea hydrothermal vent systems and contribute substantially to the primary productivity of these ecosystems (reviewed by Campbell et al., 2006). Two orders are currently described within the class Epsilonproteobacteria: Nautiliales and Campylobacterales (Miroshnichenko et al., 2004; Garrity

tPresent address: Department of Microbiology, University of Massachusetts, Amherst, MA 01003, USA.

The GenBank/EMBL/DDBJ accession number for the $16 \mathrm{~S}$ rRNA gene sequence of strain $\mathrm{MB}-1^{\top}$ is $\mathrm{FJ} 532475$.

Supplementary figures showing the generation times of strain MB- $1^{\top}$ with different growth conditions and nitrate consumption and ammonium formation during growth are available with the online version of this paper. et al., 2005). The order Nautiliales comprises the genera Caminibacter, Nautilia and Lebetimonas (Alain et al., 2002; Miroshnichenko et al., 2002; Takai et al., 2005), which include hydrogen-oxidizing bacteria isolated from deep-sea hydrothermal vents. These bacteria have been found in association with invertebrates, chimney edifices or in situ colonization devices. At present, the genus Nautilia contains three anaerobic, thermophilic chemolithotrophic species: Nautilia lithotrophica (Miroshnichenko et al., 2002), N. profundicola (Smith et al., 2008) and N. abyssi (Alain et al., 2009). In this study, we describe a novel thermophilic, chemosynthetic, strictly anaerobic, nitrateammonifying epsilonproteobacterium that was isolated from a deep-sea hydrothermal vent on the East Pacific Rise at $9^{\circ} 50^{\prime} \mathrm{N} 104^{\circ} 17^{\prime} \mathrm{W}$.

Fragments of active, high-temperature, black smoker chimneys were collected from the L-vent field (fluid temperature $346{ }^{\circ} \mathrm{C}$ ) on the East Pacific Rise at a depth 
of $2523 \mathrm{~m}$ during R/V Atlantis cruise AT 15-6 (July 2006). The samples were collected using the manipulator of DSV Alvin and stored in boxes on the submersible's working platform for the rest of the dive. On the surface, samples were transferred to the ship's laboratory and subsamples were stored at $4{ }^{\circ} \mathrm{C}$ under a $\mathrm{N}_{2}$ atmosphere. Enrichment cultures for thermophilic, chemolithoautotrophic organisms were obtained by inoculating $10 \mathrm{ml}$ modified SME medium (Stetter et al., 1983; Vetriani et al., 2004), supplemented with $10 \%(\mathrm{w} / \mathrm{v})$ nitrate under a $\mathrm{H}_{2} / \mathrm{CO}_{2}$ gas phase $(80: 20 ; 200 \mathrm{kPa})$, with $1 \mathrm{~g}$ of the black smoker chimney sample resuspended in $1 \mathrm{ml}$ anaerobic artificial seawater. The primary enrichments were incubated shipboard at $28{ }^{\circ} \mathrm{C}$. Aliquots $(0.1 \mathrm{ml})$ of the original cultures were subsequently transferred to fresh medium back in the laboratory and pure cultures were isolated by three consecutive series of dilutions followed by isolation of single colonies on plates containing SME medium solidified with $1 \mathrm{~g}$ Phytagel (Sigma) $1^{-1}$. Plates were incubated in an anaerobic jar (Oxoid) pressurized with $\mathrm{H}_{2} /$ $\mathrm{CO}_{2}(80: 20 ; 200 \mathrm{kPa})$. During the isolation procedures, cultures were incubated at $35{ }^{\circ} \mathrm{C}$. The pure culture obtained using this procedure was designated strain $\mathrm{MB}-1^{\mathrm{T}}$. Long-term stocks of the new isolate were prepared by adding $50 \mu \mathrm{l}$ DMSO (Fisher Scientific) to $1 \mathrm{ml}$ culture and stored at $-80{ }^{\circ} \mathrm{C}$.

Cells were routinely stained with $0.1 \%$ acridine orange and visualized with an Olympus BX 60 microscope with an oilimmersion objective (UPlanFl 100/1.3). Transmission electron micrographs were obtained as described previously (Vetriani et al., 2004). Cells of strain $\mathrm{MB}-1^{\mathrm{T}}$ were short rods, approximately $1-1.5 \mu \mathrm{m}$ long and $0.3-0.5 \mu \mathrm{m}$ wide, and divided by constriction (Fig. 1a). Cells stained Gram-negative. The organism was motile and possessed one or more polar flagella, which were observed in electron micrographs of platinum-shadowed cells (Fig. 1b). The presence of endospores was not observed.

Growth rates $\left(\mu ; \mathrm{h}^{-1}\right)$ were estimated as $\mu=\left(\ln N_{2}-\ln N_{1}\right) /$ $\left(t_{2}-t_{1}\right)$, where $N_{2}$ and $N_{1}$ are numbers of cells $\mathrm{ml}^{-1}$ at times $t_{2}$ and $t_{1}$ (in $\mathrm{h}$ ). Generation times $\left(t_{\mathrm{g}} ; \mathrm{h}\right.$ ) were calculated as $t_{\mathrm{g}}=\ln 2 / \mu$. All growth experiments were carried out in duplicate in modified SME medium supplemented with $10 \%(\mathrm{w} / \mathrm{v})$ nitrate under $\mathrm{H}_{2} / \mathrm{CO}_{2}$, unless stated otherwise. Quantitative determinations of nitrate, nitrite and ammonium were carried out spectrophotometrically using a Lachat QuickChem automated ion analyser according to the manufacturer's specifications (Diamond, 1993a, b). Qualitative determination of hydrogen sulfide was carried out as described previously (Vetriani et al., 2004).

The optimal growth temperature for strain $M B-1^{T}$ was determined by incubating cultures between 25 and $75{ }^{\circ} \mathrm{C}$ (at $5{ }^{\circ} \mathrm{C}$ intervals). Strain $\mathrm{MB}-1^{\mathrm{T}}$ grew at $25-65{ }^{\circ} \mathrm{C}$, with optimal growth at $55{ }^{\circ} \mathrm{C}$. No growth was observed at 20 or $75{ }^{\circ} \mathrm{C}$ (Supplementary Fig. S1a, available in IJSEM Online). All subsequent experiments were carried out at $55{ }^{\circ} \mathrm{C}$. The optimal salt requirement was determined by varying the concentration of $\mathrm{NaCl}$ between 5 and $45 \mathrm{~g} \mathrm{l}^{-1}$ in $5 \mathrm{~g} \mathrm{l}^{-1}$ intervals. Strain $\mathrm{MB}^{-1}{ }^{\mathrm{T}}$ grew at $\mathrm{NaCl}$ concentrations between 10 and $35 \mathrm{~g} \mathrm{l}^{-1}$ with optimal growth at $20 \mathrm{~g} \mathrm{l}^{-1}$ (no growth was observed at 5 or $40 \mathrm{~g} \mathrm{l}^{-1}$; Supplementary Fig. S1b). The optimal $\mathrm{pH}$ for growth was determined as described previously (Voordeckers et al., 2005). Growth of strain MB- $1^{\mathrm{T}}$ occurred between $\mathrm{pH} 4.5$ and 8.5, with an optimum at pH 7.0 (Supplementary Fig. S1c). Under optimal conditions, the generation time of strain $\mathrm{MB}-1^{\mathrm{T}}$ was $45.6 \mathrm{~min}$. Strain $\mathrm{MB}-1^{\mathrm{T}}$ was a strictly anaerobic, chemolithoautotrophic bacterium that used nitrate, hydrogen and carbon dioxide as the terminal electron acceptor, electron donor and carbon source, respectively. Under these conditions, nitrate was reduced to ammonium in stoichiometric amounts and nitrite did not accumulate in the culture medium (Supplementary Fig. S2).

Antibiotic resistance was tested in the presence of ampicillin, chloramphenicol, kanamycin and streptomycin $\left(100 \mu \mathrm{g} \mathrm{ml}^{-1}\right)$. All antibiotics were added aseptically before incubation at $55{ }^{\circ} \mathrm{C}$ and an ethanol control was performed for chloramphenicol. Growth of strain $\mathrm{MB}-1^{\mathrm{T}}$ was inhibited by all four antibiotics tested. Strain $M B-1^{\mathrm{T}}$ exhibited catalase activity, detected by the formation of gas bubbles after concentrated cells were resuspended in $70 \mu \mathrm{l}$ of a $3 \%$ solution of $\mathrm{H}_{2} \mathrm{O}_{2}$ at room temperature.

The effect of organic substrates on the growth of strain MB- $1^{\mathrm{T}}$ was investigated by adding the following substrates to the medium under $\mathrm{H}_{2} / \mathrm{CO}_{2}$ : lactate, peptone, tryptone, acetate, formate, Casamino acids, (+)-D-glucose, sucrose,
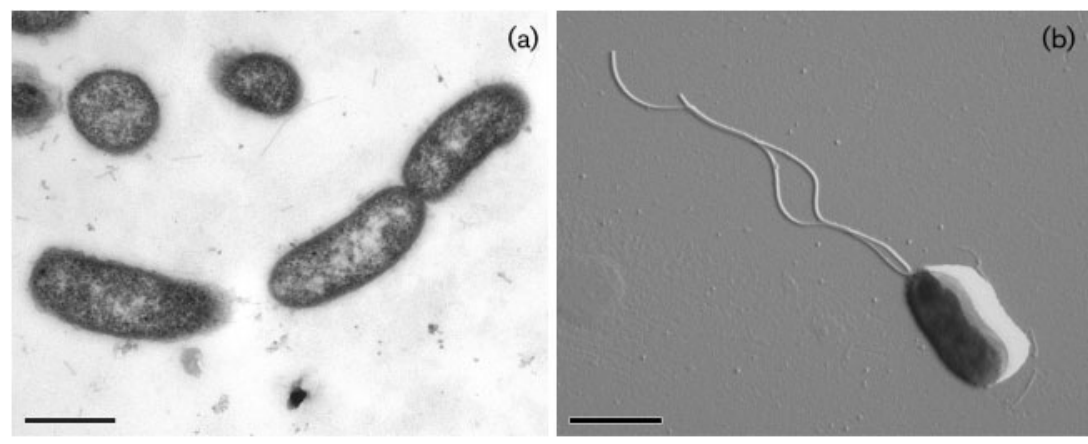

Fig. 1. Electron micrographs of strain $M B-1^{\top}$; thin section of cells showing cell morphology and division by constriction (a) and platinumshadowed cell showing multiple polar flagella (b). Bars, $0.5 \mu \mathrm{m}$ (a) and $1.0 \mu \mathrm{m}$ (b). 
fructose, galactose (each at $2 \mathrm{~g} \mathrm{l}^{-1}$ ) and yeast extract $(0.1$ and $\left.1 \mathrm{~g} \mathrm{l}^{-1}\right)$. Under $\mathrm{H}_{2} / \mathrm{CO}_{2}$, no growth occurred in the presence of lactate, peptone or tryptone, suboptimal growth occurred in the presence of acetate and formate (the generation time was several hours) and no inhibition of growth occurred in the presence of Casamino acids, glucose, sucrose, fructose, galactose or yeast extract $(0.1$ and $1.0 \mathrm{~g} \mathrm{l}^{-1}$ ). These substrates were also tested as possible energy and/or carbon sources by using the following gas phases: $\mathrm{N}_{2} / \mathrm{CO}_{2}(80: 20 ; 200 \mathrm{kPa}), \mathrm{N}_{2}(100 \% ; 200 \mathrm{kPa})$ and $\mathrm{H}_{2}(100 \% ; 200 \mathrm{kPa})$. Strain MB-1 ${ }^{\mathrm{T}}$ grew in the presence of acetate, formate, Casamino acids, sucrose, galactose and yeast extract $\left(0.1 \mathrm{~g} \mathrm{l}^{-1}\right)$ under $\mathrm{N}_{2} / \mathrm{CO}_{2}$, indicating that the strain could use these substrates as electron donors in addition to $\mathrm{H}_{2}$. However, under $\mathrm{N}_{2}$, strain $\mathrm{MB}-1^{\mathrm{T}}$ grew only in the presence of formate, indicating that the strain could only use this substrate and $\mathrm{CO}_{2}$ as carbon sources. The ability of strain $\mathrm{MB}-1^{\mathrm{T}}$ to use alternative electron acceptors was tested by adding thiosulfate $(4 \mathrm{mM})$, sulfate $(7 \mathrm{mM})$, sulfite $(4.1 \mathrm{mM})$, sulfur $(3 \%, \mathrm{w} / \mathrm{v})$, arsenate $(5 \mathrm{mM})$, selenate $(5 \mathrm{mM})$ and oxygen $(0.5 \%, \mathrm{v} / \mathrm{v})$ to nitrate-depleted medium. Strain MB- $1^{\mathrm{T}}$ did not grow when sulfate, sulfite, arsenate or oxygen were used as electron acceptors. However, strain MB-1 ${ }^{\mathrm{T}}$ was able to grow when thiosulfate, elemental sulfur or selenate was used as an electron acceptor. Generation times under these conditions were $3.8,6.0$ and $1.7 \mathrm{~h}$, respectively.

Genomic DNA was extracted from cells of strain MB- $1^{\mathrm{T}}$ by using the UltraClean microbial DNA isolation kit (MoBio). The 16S rRNA gene was selectively amplified from the genomic DNA by PCR and sequenced as described previously (Vetriani et al., 1999, 2004). Sequences were aligned automatically using CLUSTAL $\mathrm{x}$ and the alignment was refined manually using SEAVIEW (Galtier et al., 1996; Thompson et al., 1997). Neighbour-joining trees were constructed by using the least-squares algorithm of DeSoete from a normal evolutionary distance matrix, using PHYLO WIN (DeSoete, 1983; Perrière \& Gouy, 1996). Approximately 1227 homologous nucleotides were included in the analysis and bootstrap analysis with 500 replications was carried out to provide confidence estimates for phylogenetic tree topologies. The DNA $\mathrm{G}+\mathrm{C}$ content of strain $\mathrm{MB}-1^{\mathrm{T}}$ was determined by the Identification Service of the DSMZ by HPLC analysis of deoxyribonucleosides as described by Mesbah et al. (1989).

Phylogenetic analysis of the 16S rRNA gene sequence placed strain $\mathrm{MB}-1^{\mathrm{T}}$ within the class Epsilonproteobacteria (Fig. 2). Strain MB-1 ${ }^{\mathrm{T}}$ was placed in a discrete cluster in the genus Nautilia, and its next closest cultured relatives were N. profundicola $\mathrm{AmH}^{\mathrm{T}}, \quad N$. abyssi $\mathrm{PH}_{1209^{\mathrm{T}}}$ and $N$. lithotrophica $525^{\mathrm{T}}(95,94$ and $93 \%$ sequence identity, respectively). The genomic DNA $\mathrm{G}+\mathrm{C}$ content of strain $\mathrm{MB}-1^{\mathrm{T}}$ was $36.0 \mathrm{~mol} \%$.

Strain MB- $1^{\mathrm{T}}$ was assigned to the genus Nautilia, although this organism could be differentiated from previously described Nautilia species by means of several physiological

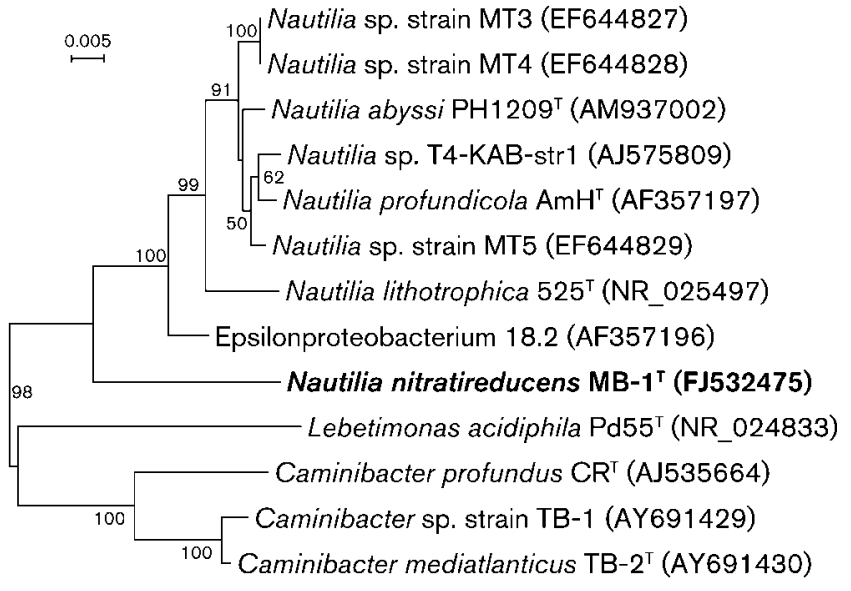

Fig. 2. Phylogenetic position of strain $M B-1^{\top}$ based on $16 \mathrm{~S}$ rRNA gene sequences in a neighbour-joining tree. Bootstrap values $(>50 \%)$ based on 500 replications are shown as percentages at branch nodes. Bar, 0.005 substitutions per nucleotide position.

characteristics (Table 1). Strain $\mathrm{MB}-1^{\mathrm{T}}$ could be distinguished from all other Nautilia species by a lower optimum salinity and its inability to grow in $\mathrm{NaCl}$ concentrations greater than $35 \mathrm{~g} \mathrm{l}^{-1}$. Furthermore, strain $\mathrm{MB}-1^{\mathrm{T}}$ has the widest temperature range among Nautilia species, and it is the only known member of the genus able to grow at $\mathrm{pH} 4.5$. Strain MB- ${ }^{\mathrm{T}}$ also differs from the other Nautilia species by its ability to use nitrate or thiosulfate as terminal electron acceptors. The generation time of strain $\mathrm{MB}-\mathrm{1}^{\mathrm{T}}$ using sulfur as terminal electron acceptor was the same as that of $N$. profundicola $(6 \mathrm{~h})$ and longer than those of $N$. lithotrophica (140 $\mathrm{min})$ and $N$. abyssi (120 $\mathrm{min})$. However, under optimal conditions (with nitrate as the terminal electron acceptor), strain $\mathrm{MB}-1^{\mathrm{T}}$ had a shorter generation time than all other Nautilia species (45.6 min). Physiological, phylogenetic and genetic analyses indicated that strain MB- $1^{\mathrm{T}}$ is not related to N. lithotrophica, N. profundicola or N. abyssi at the species level and, therefore, strain $\mathrm{MB}-1^{\mathrm{T}}$ represents a novel species within the genus Nautilia, for which we propose the name Nautilia nitratireducens sp. nov.

Epsilonproteobacteria have been recognized as playing a significant role in the ecology of deep-sea hydrothermal vents and other sulfidic environments (Campbell et al., 2006). The physiological and metabolic versatility of strain $\mathrm{MB}-1^{\mathrm{T}}$, including the wide temperature, $\mathrm{pH}$ and salinity growth ranges and its ability to utilize various terminal electron acceptors (nitrate, thiosulfate, sulfur and selenate) may contribute to its adaptability to the steep physicochemical gradients found at deep-sea vents.

\section{Description of Nautilia nitratireducens sp. nov.}

Nautilia nitratireducens (ni.tra.ti.re.du'cens. N.L. n. nitras -atis nitrate; N.L. part. adj. reducens converting to a different condition, reducing; N.L. adj. nitratireducens reducing nitrate). 
Table 1. Differentiating features of strain $\mathrm{MB}-1^{\top}$ and the type strains of $N$. profundicola, N. abyssi and $N$. lithotrophica

Strains: 1, Nautilia nitratireducens sp. nov. MB- $1^{\mathrm{T}}$ (data from this study); 2, N. profundicola $\mathrm{AmH}^{\mathrm{T}}$ (Smith et al., 2008); 3, N. abyssi PH1209 (Alain et al., 2009); 4, N. lithotrophica 525 (Miroshnichenko et al., 2002). + , Positive; -, negative; ND, no data available.

\begin{tabular}{|c|c|c|c|c|}
\hline Characteristic & 1 & 2 & 3 & 4 \\
\hline Catalase & + & + & ND & $\mathrm{ND}$ \\
\hline \multicolumn{5}{|l|}{ Temperature for growth $\left({ }^{\circ} \mathrm{C}\right)$} \\
\hline Range & $25-65$ & $30-55$ & $33-65$ & $37-68$ \\
\hline Optimum & 55 & 40 & 60 & 53 \\
\hline \multicolumn{5}{|l|}{$\mathrm{NaCl}$ concentration for growth $\left(\mathrm{g} \mathrm{l}^{-1}\right)$} \\
\hline Range & $10-35$ & $20-50$ & $20-40$ & $8-50$ \\
\hline Optimum & 20 & 30 & 30 & 30 \\
\hline \multicolumn{5}{|l|}{$\mathrm{pH}$ for growth } \\
\hline Range & $4.5-8.5$ & $6.0-9.0$ & $5.0-8.0$ & $6.4-7.4$ \\
\hline Optimum & 7.0 & 7.0 & $6.0-6.5$ & $6.8-7.0$ \\
\hline \multicolumn{5}{|l|}{ Terminal electron acceptors } \\
\hline Nitrate & + & - & - & - \\
\hline Thiosulfate & + & - & - & - \\
\hline Selenate & + & ND & $\mathrm{ND}$ & $\mathrm{ND}$ \\
\hline \multicolumn{5}{|l|}{ Electron donors } \\
\hline Acetate & + & ND & - & - \\
\hline Formate & + & + & - & + \\
\hline Yeast extract & $+\left(0.1 \mathrm{~g} \mathrm{l}^{-1}\right)$ & ND & - & - \\
\hline Heterotrophic growth & - & - & + & - \\
\hline Growth with formate as carbon source & + & + & - & + \\
\hline Optimum generation time $(\mathrm{h})$ & 0.75 & 6 & 2 & 2.3 \\
\hline DNA G $+\mathrm{C}$ content $(\mathrm{mol} \%)$ & 36.0 & 33.5 & 35 & 34.7 \\
\hline
\end{tabular}

Cells are rod-shaped (1-1.5 $\mu \mathrm{m}$ long, $0.3-0.5 \mu \mathrm{m}$ wide). Motile by means of one or more flagella. Obligate anaerobe. Gram-negative-staining. Catalase-positive. Growth occurs at 25-65 ${ }^{\circ} \mathrm{C}$, with $10-35 \mathrm{~g} \mathrm{NaCll}^{-1}$ and at $\mathrm{pH}$ 4.5-8.5. Optimal growth conditions are $55^{\circ} \mathrm{C}, 20 \mathrm{~g} \mathrm{NaCl} \mathrm{l}^{-1}$ and $\mathrm{pH} 7.0$ (shortest generation time $45.6 \mathrm{~min}$ ). Growth occurs under strictly anaerobic, chemolithoautotrophic conditions in the presence of $\mathrm{H}_{2}$ and $\mathrm{CO}_{2}$ with nitrate, thiosulfate, sulfur or selenate as terminal electron acceptors. The following are not utilized as electron acceptors: sulfate, sulfite, arsenate and oxygen. No growth occurs in the presence of lactate, peptone or tryptone. Acetate, formate, Casamino acids, sucrose, galactose (each at $\left.2 \mathrm{~g} \mathrm{l}^{-1}\right)$ and yeast extract $\left(0.1 \mathrm{~g} \mathrm{l}^{-1}\right)$ are used as energy sources under a $\mathrm{N}_{2} / \mathrm{CO}_{2}$ gas phase. Formate is utilized as a carbon source under a $\mathrm{N}_{2}$ gas phase. Sensitive to ampicillin, chloramphenicol, kanamycin and streptomycin $\left(100 \mathrm{mg} \mathrm{ml}^{-1}\right)$. The genomic DNA G $+\mathrm{C}$ content of the type strain is $36.0 \mathrm{~mol} \%$.

The type strain is MB- $1^{\mathrm{T}}\left(=\mathrm{DSM} 22087^{\mathrm{T}}=\mathrm{JCM} 15746^{\mathrm{T}}\right)$, which was isolated from the walls of an active deep-sea hydrothermal vent on the East Pacific Rise at $9^{\circ} 50^{\prime} \mathrm{N} 104^{\circ}$ $17^{\prime} \mathrm{W}$.

\section{Acknowledgements}

We thank Alberto Domenighini, Sarat Kannepalli and Ronald Lauck for excellent technical assistance. We wish to thank the crew of R/V
Atlantis and the crew and pilots of the DSV Alvin for their skilled operations at sea. This work was supported by NSF grants MCB 0456676, OCE 03-27353 and MCB 08-43678 to C. V. and by the New Jersey Agricultural and Experiment Station.

\section{References}

Alain, K., Querellou, J., Lesongeur, F., Pignet, P., Crassous, P., Raguénès, G., Cueff, V. \& Cambon-Bonavita, M.-A. (2002). Caminibacter hydrogeniphilus gen. nov., sp nov., a novel thermophilic, hydrogen-oxidizing bacterium isolated from an East Pacific Rise hydrothermal vent. Int J Syst Evol Microbiol 52, 1317-1323.

Alain, K., Callac, N., Guégan, M., Lesongeur, F., Crassous, P., Cambon-Bonavita, M.-A., Querellou, J. \& Prieur, D. (2009). Nautilia abyssi sp. nov., a thermophilic, chemolithoautotrophic, sulfurreducing bacterium isolated from an East Pacific Rise hydrothermal vent. Int J Syst Evol Microbiol 59, 1310-1315.

Campbell, B. J., Engel, A. S., Porter, M. L. \& Takai, K. (2006). The versatile epsilon-proteobacteria: key players in sulphidic habitats. Nat Rev Microbiol 4, 458-468.

DeSoete, G. (1983). A least squares algorithm for fitting additive trees to proximity data. Psychometrika 48, 621-626.

Diamond, D. (1993a). Nitrate in brackish or seawater. In QuickChem Automated Ion Analyzer Methods Manual, method 31-107-04-1-A. Milwaukee, WI: Lachat Instruments.

Diamond, D. (1993b). Ammonia in brackish or seawater. In QuickChem Automated Ion Analyzer Methods Manual, method 31107-06-1-A. Milwaukee, WI: Lachat Instruments. 
Galtier, N., Gouy, M. \& Gautier, C. (1996). SEAVIEW and PHYLO_WIN: two graphic tools for sequence alignment and molecular phylogeny. Comput Appl Biosci 12, 543-548.

Garrity, G. M., Bell, J. A. \& Lilburn, T. (2005). Order I. Campylobacterales ord. nov. In Bergey's Manual of Systematic Bacteriology, 2nd edn, vol. 2, part C, p. 1145. Edited by D. J. Brenner, N. R. Krieg, J. T. Staley \& G. M. Garrity. New York: Springer.

Mesbah, M., Premachandran, U. \& Whitman, W. B. (1989). Precise measurement of the $\mathrm{G}+\mathrm{C}$ content of deoxyribonucleic acid by highperformance liquid chromatography. Int J Syst Bacteriol 39, 159-167.

Miroshnichenko, M. L., Kostrikina, N. A., L'Haridon, S., Jeanthon, C., Hippe, H., Stackebrandt, E. \& Bonch-Osmolovskaya, E. A. (2002). Nautilia lithotrophica gen. nov., sp nov., a thermophilic sulfurreducing $\varepsilon$-proteobacterium isolated from a deep-sea hydrothermal vent. Int J Syst Evol Microbiol 52, 1299-1304.

Miroshnichenko, M. L., L'Haridon, S., Schumann, P., Spring, S., Bonch-Osmolovskaya, E. A., Jeanthon, C. \& Stackebrandt, E. (2004). Caminibacter profundus sp. nov., a novel thermophile of Nautiliales ord. nov. within the class 'Epsilonproteobacteria', isolated from a deep-sea hydrothermal vent. Int J Syst Evol Microbiol 54, 4145.

Perrière, G. \& Gouy, M. (1996). WWW-Query: an on-line retrieval system for biological sequence banks. Biochimie 78, 364-369.

Smith, J. L., Campbell, B. J., Hanson, T. E., Zhang, C. L. \& Cary, S. C. (2008). Nautilia profundicola sp. nov., a thermophilic, sulfur-reducing epsilonproteobacterium from deep-sea hydrothermal vents. Int J Syst Evol Microbiol 58, 1598-1602.
Stetter, K. O., König, H. \& Stackebrandt, E. (1983). Pyrodictium gen. nov., a new genus of submarine disc-shaped sulfur-reducing archaebacteria growing optimally at $105{ }^{\circ} \mathrm{C}$. Syst Appl Microbiol 4, 535-551.

Takai, K., Hirayama, H., Nakagawa, T., Suzuki, Y., Nealson, K. H. \& Horikoshi, K. (2005). Lebetimonas acidiphila gen. nov., sp. nov., a novel thermophilic, acidophilic, hydrogen-oxidizing chemolithoautotroph within the 'Epsilonproteobacteria', isolated from a deep-sea hydrothermal fumarole in the Mariana Arc. Int J Syst Evol Microbiol 55, 183-189.

Thompson, J. D., Gibson, T. J., Plewniak, F., Jeanmougin, F. \& Higgins, D. G. (1997). The CLUSTAL_X Windows interface: flexible strategies for multiple sequence alignment aided by quality analysis tools. Nucleic Acids Res 25, 4876-4882.

Vetriani, C., Jannasch, H. W., MacGregor, B. J., Stahl, D. A. \& Reysenbach, A. L. (1999). Population structure and phylogenetic characterization of marine benthic archaea in deep-sea sediments. Appl Environ Microbiol 65, 4375-4384.

Vetriani, C., Speck, M. D., Ellor, S. V., Lutz, R. A. \& Starovoytov, V. (2004). Thermovibrio ammonificans sp. nov., a thermophilic, chemolithotrophic, nitrate-ammonifying bacterium from deep-sea hydrothermal vents. Int J Syst Evol Microbiol 54, 175-181.

Voordeckers, J. W., Starovoytov, V. \& Vetriani, C. (2005). Caminibacter mediatlanticus sp. nov., a thermophilic, chemolithoautotrophic, nitrate-ammonifying bacterium isolated from a deep-sea hydrothermal vent on the Mid-Atlantic Ridge. Int $J$ Syst Evol Microbiol 55, 773-779. 